\title{
Aplikasi Penjadwalan Belajar Mengajar Pada Bimbingan Belajar Dengan Menggunakan Metode Waterfall
}

\author{
Rachmat Hidayat, M.Kom ${ }^{1}$, Asep Sayfulloh, M. Kom² \\ ${ }^{1}$ Jurusan Teknologi Informasi,Universitas Bina Sarana Informatika, rachmat.rch@bsi.ac.id \\ ${ }^{2}$ Jurusan Teknologi Informasi,Universitas Bina Sarana Informatika, asep.alo@bsi.ac.id
}

\section{Keywords:}

Information Systems,

Tutoring,

Waterfall,

\begin{abstract}
The internet has been widely used in various fields, such as information, telecommunications, trade, to education, making it easier for a company or institution to provide information that is very useful for the community. tutoring education. Researchers conducted a case study at tutoring sites in Tangerang City, including ELC English tutoring, Rizki General Bimbel, AlHikmah Religious Education, with a large number of students and teachers, still applying the conventional scheduling system, where the admin will contact students and teachers by telephone if there are teaching classes, other obstacles the admin forgets to notify students and teachers if there is a schedule, the schedule given is not appropriate and clashes with other classes, students or teachers cannot contact the admin to get schedule information. By utilizing information technology, these problems can be facilitated by making a web-based scheduling application developed using the waterfall method. This development method includes needs analysis, design, implementation, and testing. In the needs analysis stage, business process modeling is carried out based on the results of interviews with stakeholders and problem analysis. The results of the application design produce applications that can perform scheduler management of teacher data, lesson data and student data, which will be stored in the database.
\end{abstract}

\section{Kata Kunci}

Sistem Informasi,

Bimbingan Belajar,

Waterfall

\begin{abstract}
ABSTRAK
Internet sudah banyak digunakan dalam berbagai bidang, seperti informasi, telekomunikasi, perdagangan, hingga pendidikan, sehingga memudahkan suatu perusahaan atau institusi memberikan informasi yang sangat berguna bagi masyarakat terkadang masih ada juga instansi yang belum menggunakan aplikasi berbasi web untuk kegiatan usahanya, salah satunya adalah lembaga pendidikan bimbingan belajar. Peneliti melakukan studi kasus ketempat bimbingan belajar yang ada di Kota Tangerang, diantaranya bimbing belajar Bahasa Inggris ELC, Bimbel Umum Rizki, Bimbel Agama Al-Hikmah,dengan jumlah siswa dan pengajar yang banyak,masih menerapkan sistem penjadwalan secara konvensional, dimana pihak admin akan menghubungi siswa dan pengajar melalui telepon jika ada kelas pengajaran, kendala lainya pihak admin lupa memberitahukan ke siswa dan pengajar jika ada jadwal, jadwal yang diberikan tidak sesuai dan bentrok dengan kelas lain, siswa atau pengajar tidak dapat menghubungi pihak admin untuk mendapatkan informasi jadwal.Dengan memafaatkan teknologi informasi permasalahan tersebut dapat dipermudah dengan dibuatkan aplikasi penjadwalan berbasis web yang dikembangkan dengan metode waterfall. Metode pengembangan ini meliputi analisis kebutuhan, perancangan, implementasi, dan pengujian. Pada tahap analisis kebutuhan dilakukan pemodelan proses bisnis yang dibuat berdasarkan hasil wawancaradengan stakeholder dan analisis permasalahan. Hasil perancangan aplikasi menghasilkan aplikasi yang dapat melakukan manajemen pengelolahan penjadwal data pengajar, data pelajararan dan data siswa, yang akan tersimpan didalam database.
\end{abstract}




\section{Korespondensi Penulis:}

Rachmat Hidayat, M.Kom

Universitas Bina Sarana Informatika

Jl. Kramat Raya No. 98 RT. 02/RW. 9, kwitang, Kec. Senen, Kota Jakarta Pusat, 10450

Telepon: +6281574311969

Email: rachmat.rch@bsi.ac.id

\section{PENDAHULUAN}

Pada saat ini aplikasi website telah banyak yang bersifat dinamis serta interaktif dan digunakan dalam berbagai bidang, seperti informasi, telekomunikasi, perdagangan, hingga pendidikan, sehingga memudahkan suatu perusahaan atau institusi memberikan informasi yang jangkauannya lebih luas kepada masyarakat pada umumnya.Pemanfaatan Teknologi Informasi dan Komunikasi (TIK) pada bidang layanan administrasi akademik di perguruan tinggi menjadi suatu kebutuhan, bukan hanya sekedar prestise atau lifestyle manajemen pendidikan tinggi modern. Namun dalam implementasinya, banyak kendala yang ditemui perguruan tinggi dalam menerapkan TIK dalam proses pengelolaan kelembagaan ini baik faktor teknis maupun non teknis[1]

Bimbingan belajar merupakan sebuah lembaga yang bertujuan untuk menyalurkan kemampuan para siswa belajar dari berbagai jurusan untuk dapat membagikan ilmunya kepada masyarakat. Saat ini bimbingan belajar di Kota Tangerang sangat banyak dan berkembang, menyediakan bimbingan secara privat maupun kelompok yang terdiri dari bimbingan untuk siswanya sendiri dari usia 7 tahun hingga dewasa.Salah satu permasalahan yang penulis temukan dibeberapa tempat Bimbingan Belajar atau lembaga Bimbeladalah sisteminformasi penjadwalan proses belajar mengajar masih bersifat lisan atau manual melalui telepon. Kebanyakan lembaga bimbingan belajar belum mengetahui betapa pentingannya sistem informasi menggunakan website agar peserta didik dapat mengetahui informasi jadwal belajar pada lembaga bimbingan belajar tersebut seuai harapan.Banyaknya tempat bimbingan belajaryang ada, penulis hanya mengambil Tiga(3) tempat sebagai objek Penulisan dengan cara Observasi, Bimbel Bahasa Inggris ELC, Bimbel Umum Rizki, Lembaga Bimbingan Belajar Al-Hikmah, dimana Tiga tempat tersebut memiliki Permasalahan yang sama hanya beda pelaksanaaanya dalam hal penjadwalan belajar mengajar.

Tujuan penulisan ini adalah memberikan solusi masalah yang terjadi pada lembaga bimbingan belajar, khususnya mengenai sistem informasi penjadwalan belajar mengajar, mengelolah data siswa dan pengajar di kelompokkan kedalam 1 database, membantu siswa dan pengajar mendapatkan informasi terkait jadwal yang lebih cepat melalui media internetdengan membuatkan aplikasi penjadwalan berbasis web, diantaranya informasi data pengajar, data pelajaran dan jadwal mengajar yang bisa diberikan lebih cepat sampainya dan data lebih aman tersimpan,dalam pembuatan aplikasi penjadwalan, menggunakan metode air terjun atau waterfall.Model ini merupakan model yang paling pertama dipublikasikan. Model ini berasal dari proses sistem engineering yang lebih umum. Karena proses dari tahap satu ke tahap selanjutnya mengalir ke bawah, model ini dikenal sebagai waterfall model atau siklus hidup software[2].

\section{METODE PENELITIAN}

\subsection{Sistem Informasi}

Sistem informasi mencakup sejumlah komponen (manusia, komputer, teknologi informasi, dan prosedur kerja), ada sesuatu yang diproses (data menjadi informasi), dan dimaksudkan untuk mencapai suatu sasaran atau tujuan[3].

\subsection{Pengenalan Website}

Website adalah sejumlah halaman yang memiliki topik saling terkait, terkadang disertai pula dengan berkas-berkas gambar, video, atau jenis-jenis berkas lainnya. Sebuah website biasanya ditempatkan setidaknya pada sebuah web server yang dapat diakses smelalui jaringan seperti internet, ataupun jaringan wilayah lokal (LAN) melalui alamat internet yang dikenali sebagai Uniform Resource Locator (URL). Websiteberdasarkan teknologinya dibagi mejadi dua yaitu website statis dan website dinamis. Website statis adalah website yang menampilkan informasi-informasi yang bersifat tetap. Disebut statis karena pengguna tidak dapat berinteraksi dengan website tersebut. Websitedinamis adalah website yang menampilkan informasi serta dapat berinteraksidengan pengguna. Website dinamis memungkinkan pengguna untuk berinteraksi menggunakan form sehingga dapat mengolah informasi sehingga dapat mengolah informasi yang ditampilkan. Website dinamis bersifat interaktif, tidak kaku, dan terlihat lebih indah.World Wide Web (WWW atau Web) merupakan sistem infomasi tertribusi yang berbasis hypertexty [4]

\subsection{Model Pengembangan System}

Waterfall Model adalah model klasik yang bersifat sistematis, berurutan dalam membangun software. Waterfall Model terdiri dari 5 tahapan untuk pengembangan[5]. 
- Siswa dapat melihat informasi jadwal mata pelajaran bimbingan. Siswa dapat melihat dan mengunduh materi dan soal berformat softcopy(.pdf).

\begin{tabular}{|c|c|c|c|c|c|c|}
\hline \multicolumn{7}{|c|}{ HEADER } \\
\hline BERANDA & \multirow{3}{*}{\multicolumn{6}{|c|}{ DATA MATA PELAJARAN }} \\
\hline DATA SISWA & & & & & & \\
\hline DATA PENGAJAR & & & & & & \\
\hline DATA MATA PELAJARAN & \multirow{4}{*}{ 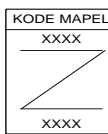 } & \multirow{4}{*}{$\sum_{x x x x x x x x x x x}^{\frac{\text { MAPEL }}{x x x x x x x x x x}}$} & \multirow{4}{*}{$\sum_{x x y x x y x x y x}^{x}$} & \multirow{2}{*}{$\begin{array}{c}\text { MODUL } \\
x x x x x x x x x x x\end{array}$} & \multirow{3}{*}{\begin{tabular}{|l|} 
EDIT \\
EDIT \\
EDIT \\
EDIT \\
\end{tabular}} & \\
\hline DATA JADWAL PELAJARAN & & & & & & HAPUS \\
\hline DATA ADMINISTRATOR & & & & & & HAPUS \\
\hline KELUAR & & & & $x \times x x x x x x x x$ & & HAPUS \\
\hline & & & & & & \\
\hline & & EOOTER & & & & \\
\hline
\end{tabular}

Gambar 4. Halaman Data Mata Pelajaran

\section{Construction (Code \& Test)}

Tahapan ini merupakan proses bentuk desain menjadi kode atau bentuk bahasa yang dapatdibaca oleh mesin. Setelah pengkodean selesai, dilakukan pengujian terhadap sistem dan juga kode yang sudah dibuat. Tujuannya untuk menemukan kesalahan yang mungkin terjadi untuk nantinya diperbaiki.

a. Pembuatan Halaman Login dengan perangkat lunak notepade++ sebagai berikut :

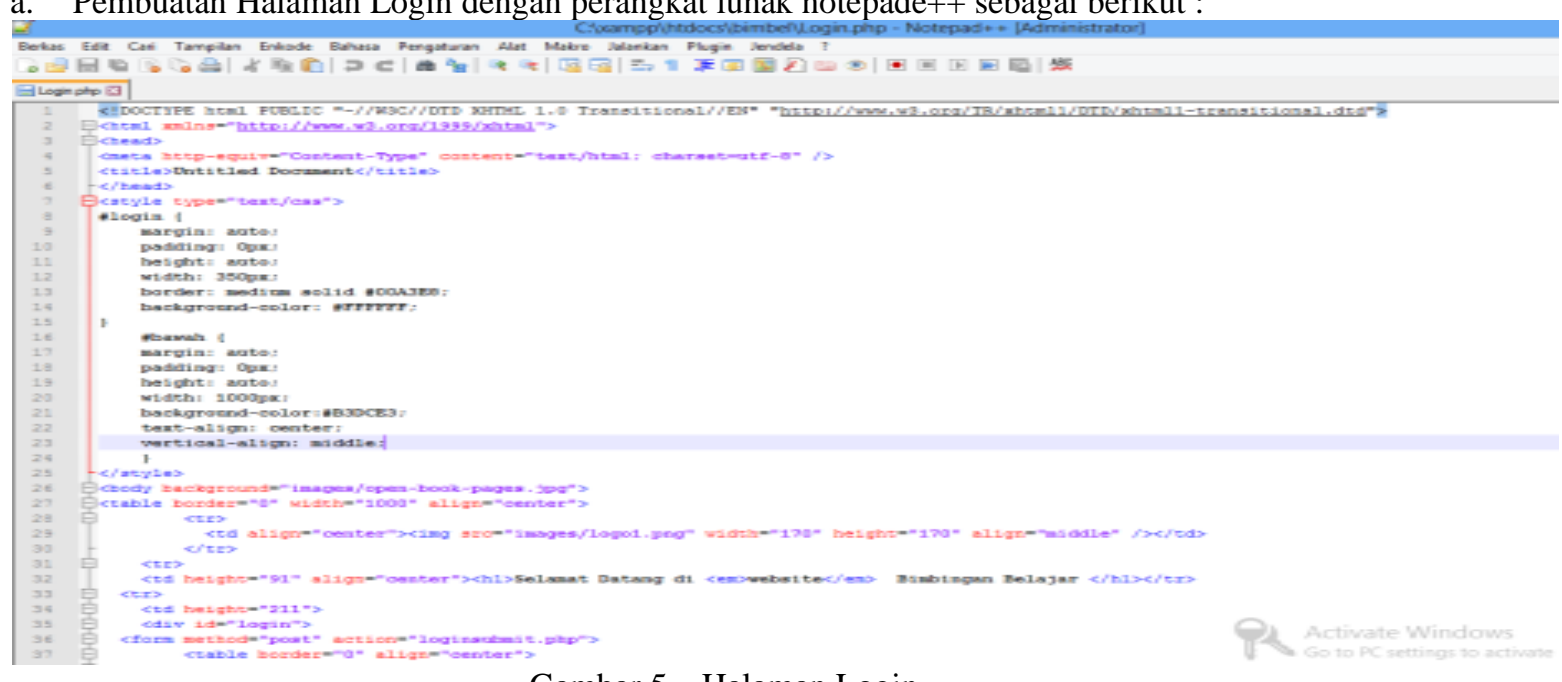

Gambar 5. Halaman Login

b. Pembuatan Halaman Utama dengan perangkat lunak notepade++ sebagai berikut :

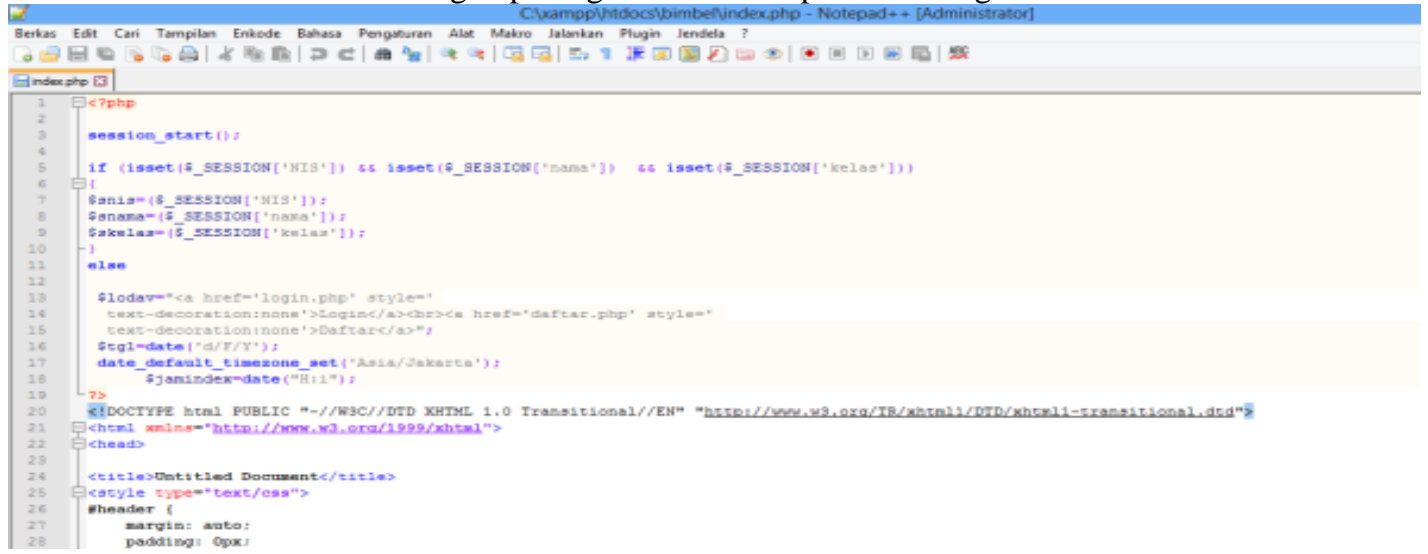

Gambar 6. Halaman Utama 
c. Pembuatan Halaman Utama dengan perangkat lunak notepade++ sebagai berikut :

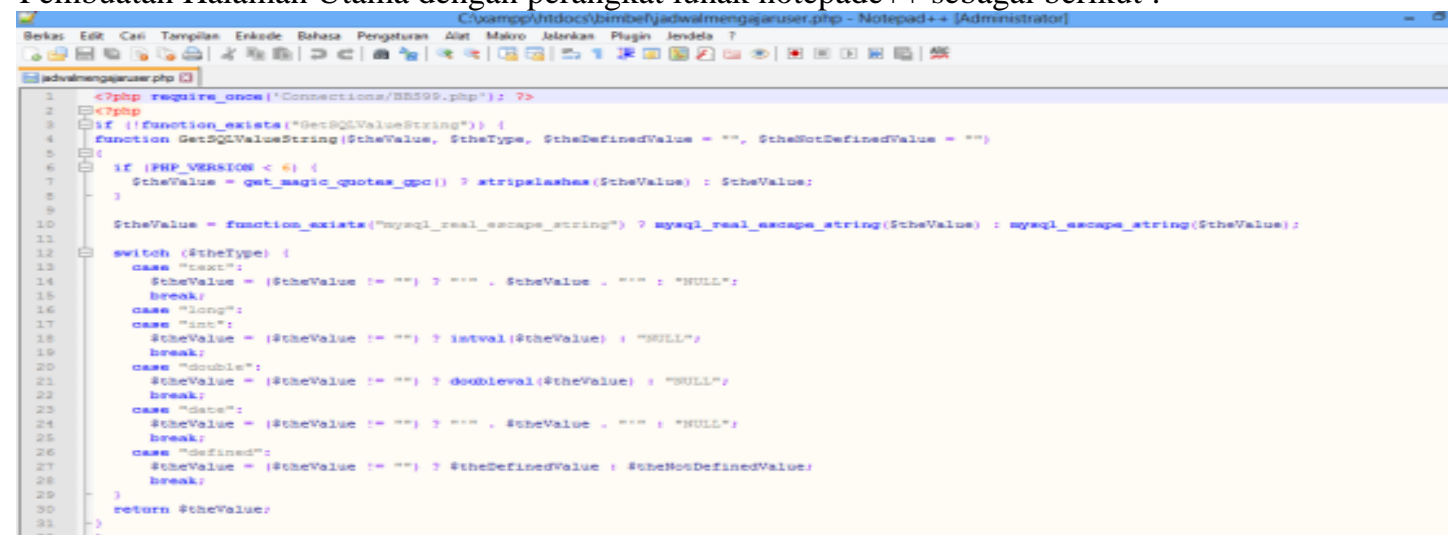

Gambar 7. Halaman Data Pengajar

\section{Development (Delivery, Support, Feedback)}

Tahapan terakhir ini merupakan tahapan implementasi software ke customer agar sistem dapat tetap berjalan dan berkembang sesuai dengan fungsinya, desain tampilan sebagai berikut:

a. Pembuatan Halaman Login dengan perangkat lunak dreamwaver sebagai berikut:

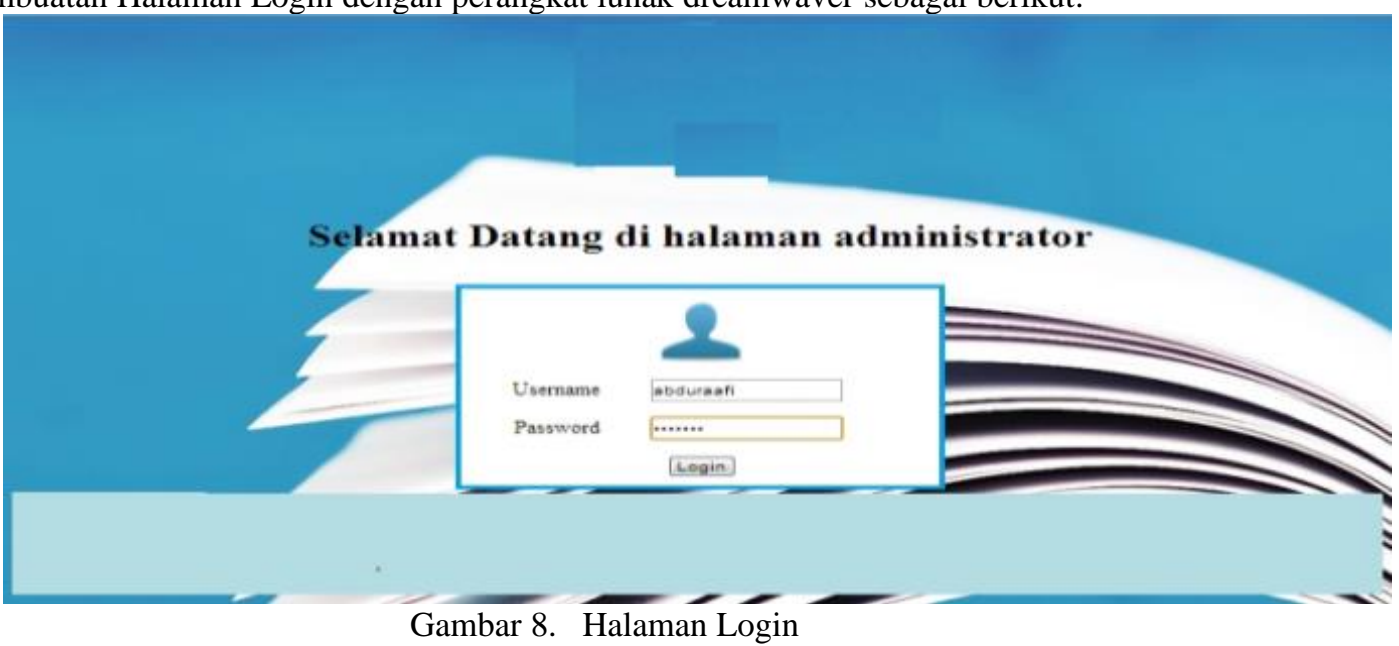

b. Pembuatan Halaman Utama dengan perangkat lunak dreamwaver sebagai berikut :

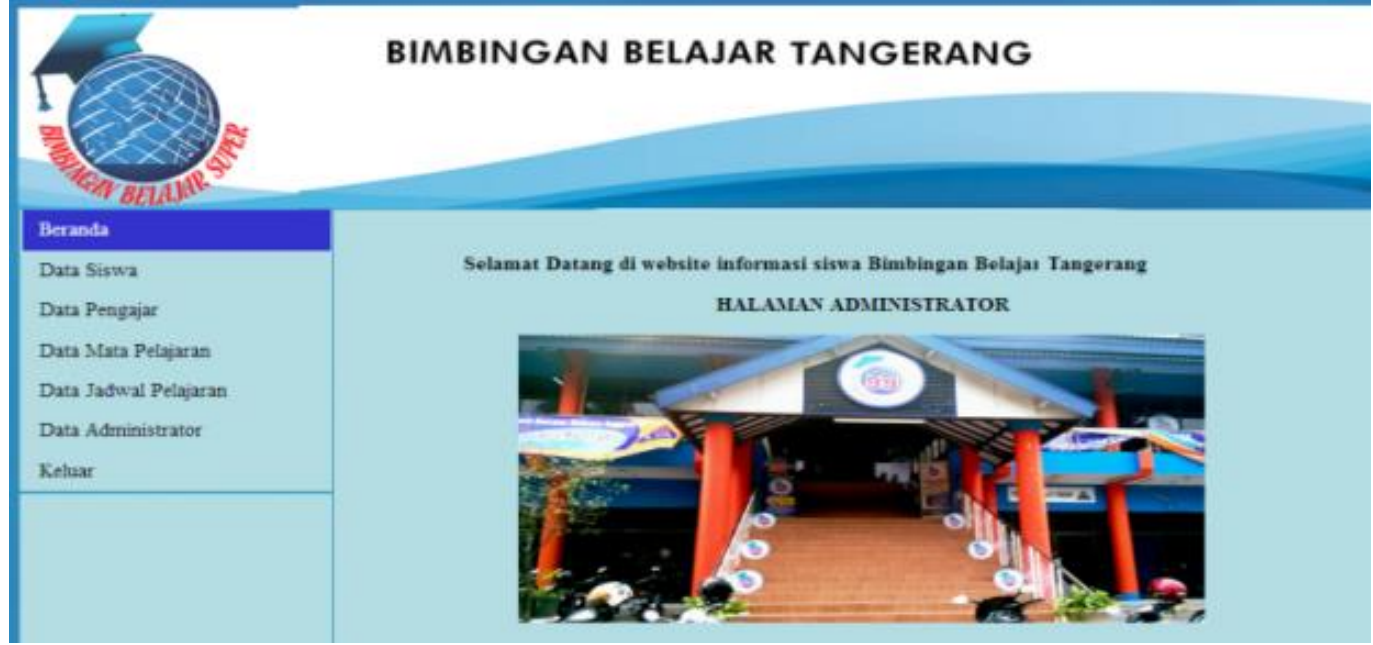

Gambar 9. Halaman Utama 
c. Pembuatan Halaman Jadwal Mengajar dengan perangkat lunak dreamwaver sebagai berikut :

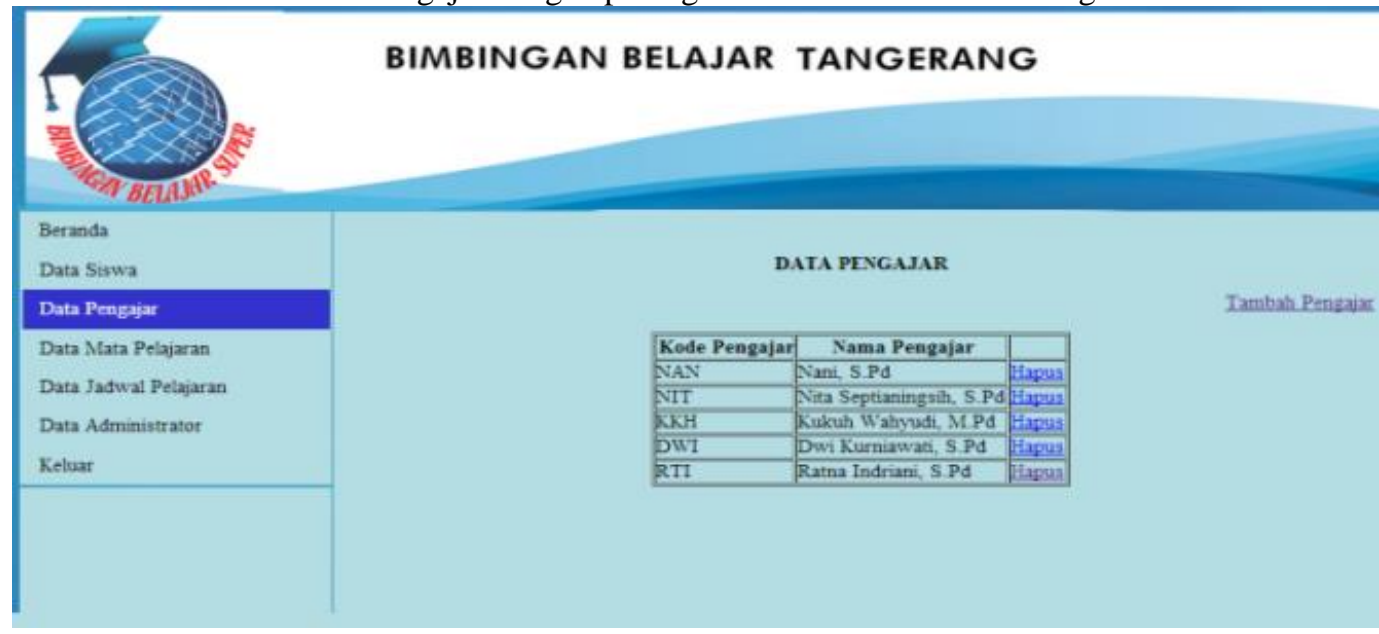

Gambar 10. Halaman Data Pengajar

\section{Testing}

Pada tahap ini dilakukan penggabungan halaman-halaman program yang sudah di desain dan sudah dibuatsebelumnya. Setelah itu akan dilakukan pengujian dengan teknik pengujian menggunakan pengujian blackbox, yang bertujuan untuk mengetahui apakah software sudah sesuai desain yang diinginkan dan apakah masih ada kesalahan atau tidak.dalam pengujian program login apakah sdh memenuhi atau blm.

\section{Maintenance}

Maintenance adalah tahapan terakhir dari metode pengembangan waterfall. Di sini software yang sudah jadi akan dijalankan atau dioperasikan oleh penggunanya. Saat ini aplikasi sudah siap di implementasikan dan dijalankan, dikarenakan masih terkendala kebijakan, pada masing-masing lembaga untuk penggunaan aplikasi saat ini belum bisa di jalankan.

\subsection{Teknik Pengumpulan Data}

Observasi

Untuk mendapatkan data, penulis melakukan pengamatan dan melakukan pencatatan secara langsung permasalahan pada tempat bimbingan belajar di kota tangerang yaitu Bimbel Bahasa Inggris ELC, Bimbel Umum Rizki, Lembaga Bimbingan Belajar Al-Hikmahdan memberikan solusi mengenai sistem informasi penerimaan penjadwalan belajar mengajar siswa dan pengajar.

\section{Wawancaraa}

Selain mengumpulkan data melalui observasi penulis juga mengumpulkan data dengan mewawancarai kepala pihak pimipinan atau yang mewakili bimbingan belajar di Kota Tangerang.

\section{Studi Pustaka}

Selain observasi dan wawancara penulis mengumpulkan data guna melengkapi penulisan dengan mempelajari bahan-jurnal, konsep, teori-teori, dan buku yang menunjang atau berkaitan dengan masalah yang diamati.

\subsection{Basis Data (Database)}

Untuk membuat suatu program diperlukan sebuah database untuk menampung semua data yang diperlukan. Ada banyak tools atau aplikasi yang bisa digunakan untuk membuat database diantaranya menggunakan Microsoft Accses, SQL Server, MySQL.Database atau memiliki istilah lain basis data merupakan suatu kumpulan data yang saling berhubungan dan berkaitan dengan subjek tertentu pada tujuan tertentu pula[5]

MySQL memiliki beberapa kelebihan dibandingkan dengan database lain, yaitu:

a. Banyak ahli berpendapat $M y S Q L$ merupakan Server tercepat.

b. MySQL merupakan system managementdatabase yang Open Source (kode sumbernya terbuka), yaitu software ini bersifat free atau bebas digunakan oleh perorangan atau instansi tanpa harus membeli atau membayar kepada pembuatnya.

c. DatabaseMySQL mengerti bahasa $S Q L$ (Structured Query Language).

d. MySQL merupakan database yang mampu menyimpan data berkapasitas besar, hingga ukuran GigaByte.

e. MySQL dapat berjalan diberbagai operatingsystem seperti Linux, Windows, Solaris, dan lain-lain.

f. MySQL dapat diakses melalui protokol ODBC (Open Database Connectivity) buatan Microsoft

Semua klien dapat mengakses server dalam satu waktu, tanpa harus menunggu yang lain untuk mengakses database. 


\subsection{PengujianWeb}

Sebelum sistem diterapkan, sistem harus melewati tahap pengujian, baik pengujian sistem maupun pengujian program. Hal ini dilakukan untuk mengidentifikasi bila terjadi kesalahan ataupun terdapatnya celah pada sistem. Pengujian ini dilakukan pada semua modul yang telah terintegrasi. Pengujian program dilakukan untuk mengetahui, apakah sistem ini sudah layak untuk diterapkan pada lembaga bimbingan belajar tersebut atau belum.

Pengujian blackbox testing terfokus pada apakah unit program memenuhi kebutuhan (requirement) yang disebut dalam spesifikasi [6]. Pada blackbox testing, cara pengujian hanya dilakukan dengan menjalankan atau mengeksekusi unit atau modul, kemudian diamati apakah hasil dari unit itu sesuai dengan proses bisnis yang diinginkan.

\subsection{Struktur Navigasi}

struktur navigasi adalah susunan menu atau hierarki dari situs yang menggambarkan isi dari setiap halaman dan link atau navigasi tiap halaman pada suatu website.[7]. Stuktur navigasi suatu website sangat dipengaruhi oleh tujuan dari website yang akan dibuat. Struktur navigasi dapat digolongkan menurut kebutuhan akan objek, kemudahan pemakaian, interaksi antar hubungan, dan kemudahan membuatnya yang berpengaruh terhadap waktu pembuatan website. Bentuk dasar dari struktur navigasi di antaranya sebagai berikut.

1. Linear (Satu Alur)

Struktur linear merupakan struktur yang hanya mempunyai satu rangkaiancerita yang berurut. Dengan kata lain struktur ini hanya dapat menampilkan satu demi satu tampilan layar secara berurut menurur urutanya. Tampilan yang dapat ditampilkan pada struktur jenis ini adalah satu halaman sebelumnya atau satu halaman sesudahnya dan tidak dapat menampilkan dua halaman sebelumnya atau dua halaman sesudahnya. Salah satu yang terpenting dari struktur ini adalah tidak diperkenankan terjadinya percabangan.

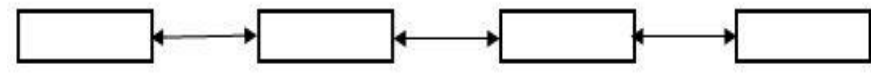

Gambar 11. Struktur Navigasi Linear

\section{Hierarchical (Hierarki)}

Struktur hierarchical (bercabang) ini percabangan untuk menampilkan data berdasarkan kriteria tertentu. Tampilan pada menu pertama akan disebut sebagai master page (halaman utama). Halaman utama ini akan mempunyai halaman percabangan yang dikatakan slave page (halaman pendukung). Jika salah satu halaman pendukung dipilih atau diaktifkan, maka tampilan tersebut akan bernama master page (halaman utama kedua), dan seterusnya. Yang terpenting dari struktur penjejakan ini tidak diperkenankan adanya tampilan secara linier.

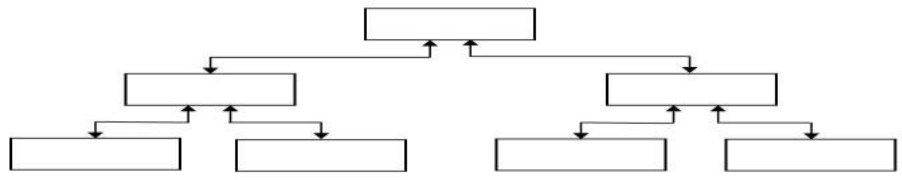

Gambar 12. Struktur Navigasi Hierarchical

3. Non-Linear(Tidak Berurut)

Struktur non linier merupakan pengembangan dari struktur linear. Pada struktur ini diperkenankan membuat penjejakan bercabang. Pemakai bebas menulusuri website tanpa dibatasi oleh suatu rute dimana kontrol navigasi dapat mengakses ke semua halaman manapun. Percabangan yang dibuat pada struktur non-linear ini berbeda dengan percabangan pada struktur Hierarchi, karena pada percabangan NonLinear ini walaupun terdapat percabangan, tetapi tiap-tiap tampilanmempunyai keduduk-an yang sama tidak ada Master Page dan Slave Page.

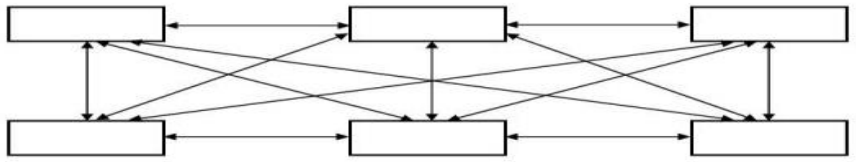

Gambar 13. Strukur Navigasi Non-Linear

4. Composite (Campuran)

Strukturcomposite atau disebut juga struktur penjejakan bebas merupakangabungan dari ketiga struktur sebelumnya yaitu Linear, Non-Linear, danHierarchical. Jika suatu tampilan membutuhkan percabangan, maka dapat dibuatpercabangan, dan bila dalam percabangan tersebut terdapat suatu tampilan yang sama kedudukannya maka dapat dibuat struktur Liner dalam percabangan tersebut. Setipa struktur peta penjajakan seperti yang baru dibahas mempunyai fungsi dan tujuan tersendiri, tidak ada yang lebih baik atau lebih buruk. Penggunanan peta penjajakan bergantung kepada kebutuhan dan tujuan dari website yang hendak dibuat. Semakin kompleks peta penjajakan yang digunakan, maka semakin sulit pula pembuatan page dari peta penjajakan tersebut. 


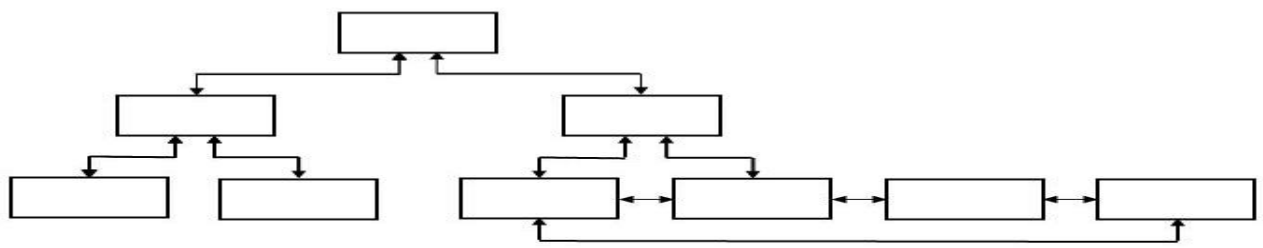

Gambar 14. Strukur Navigasi Composite

3. HASIL DAN ANALISIS

3.1 Tahap Kebutuhan (Requirments)

Pada tahap ini penulis membutuhkan beberapa Software dan hardware sesuai kebutuhan :

a. Spesifikasi Perangkat Lunak

1) Server

a) Sistem operasi yangdigunakan seperti: Microsoft Windows.

b) Aplikasi web server seperti: XAMPP, yang terdiri dari beberapa komponen:

- Aplikasi PHP Server versi 5, MySQL Server versi 5,Aplikasi phpMyAdmin versi 3

c) Aplikasi web browser seperti: Google Chrome, Mozilla Firefox, Internet Explorer, Opera, dan Safari.

2) Client

a) Sistem operasi yang digunakan seperti: Microsoft Windows dan Linux.

b) Aplikasi web browser seperti: Google Chrome, Mozilla Firefox, Internet Explorer, Opera, dan Safari.

b. Spesifikasi Perangkat Keras

1) Server
a) Laptop
- Processor Intel®
- RAM DDR 2GB
- Harddisk 320 GB
- Monitor 14" LCD
b) Koneksi internet

2) Client
a) PC,Laptop dan Notebook
b) Koneksi internet

\subsection{Tahap Desain Database}

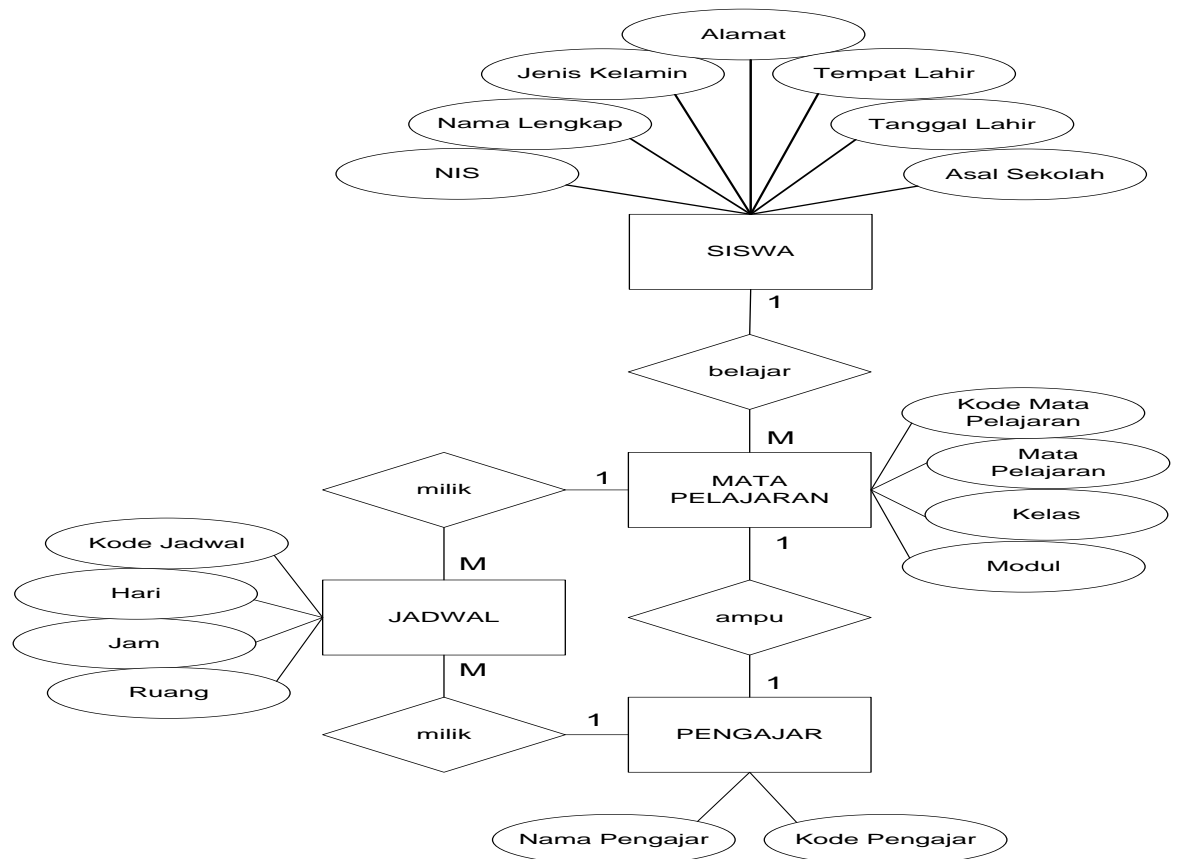

Gambar 15. Database Bimbel 
a. Spesifikasi File Siswa

Tabel 1. File Siswa

\begin{tabular}{|c|l|l|c|c|c|}
\hline No & \multicolumn{1}{|c|}{ Elemen Data } & Nama Field & Tipe & Ukuran & Keterangan \\
\hline 1 & Nomor Induk Siswa & NIS & Integer & 10 & Primary Key \\
\hline 2 & Nama Lengkap & namalengkap & Varchar & 25 & \\
\hline 3 & Jenis Kelamin & jeniskelamin & Varchar & 10 & \\
\hline 4 & Alamat & alamat & Varchar & 50 & \\
\hline 5 & Tempat Lahir & tempatlahir & Varchar & 15 & \\
\hline 6 & Tanggal Lahir & tanggallahir & Date & - & \\
\hline 7 & Asal Sekolah & asal & Varchar & 25 & \\
\hline 8 & Kelas & kelas & Varchar & 10 & \\
\hline
\end{tabular}

b. Spesifikasi File Pengajar

Tabel 2. File Pengajar

\begin{tabular}{|c|l|l|l|c|c|}
\hline No & Elemen Data & Nama Field & Tipe & Ukuran & Keterangan \\
\hline 1 & Kode Pengajar & kd_pengajar & varchar & 3 & Primary Key \\
\hline 2 & Nama Pengajar & namapengajar & varchar & 30 & \\
\hline
\end{tabular}

c. Spesifikasi File Pelajaran

Tabel 3. File Pelajaran

\begin{tabular}{|c|l|l|l|l|l|}
\hline No & Elemen Data & $\begin{array}{c}\text { Nama } \\
\text { Field }\end{array}$ & Tipe & Ukuran & Keterangan \\
\hline 1 & Kode Mapel & kd_mapel & varchar & 4 & Primary Key \\
\hline 2 & Mata Pelajaran & mapel & varchar & 20 & \\
\hline 3 & Kelas & kelas & varchar & 10 & \\
\hline 4 & Modul & modul & varchar & 50 & \\
\hline
\end{tabular}

d. Spesifikasi File Jadwal

Tabel 4. File Jadwal

\begin{tabular}{|c|l|l|l|c|c|}
\hline No & Elemen Data & Nama Field & Tipe & Ukuran & Keterangan \\
\hline 1 & Kode Jadwal & kd_jadwal & varchar & 3 & Primary Key \\
\hline 2 & Kode Mapel & kd_mapel & varchar & 4 & \\
\hline 3 & Kode Pengajar & kd_pengajar & varchar & 3 & \\
\hline 4 & Hari & hari & varchar & 6 & \\
\hline 5 & Jam & jam & varchar & 12 & \\
\hline 6 & Ruang & ruang & varchar & 3 & \\
\hline
\end{tabular}

\subsection{TahapDesain Kebutuhan User dan Administrator}

Berikut spesifikasi kebutuhan sistem.

1. Pada halaman administrator, administrator harus login terlebih dahulu untuk mendapatkan hak akses, setelah itu dapat mengelola data siswa. Selain itu, administrator dapat mengelola data pengajar. Administrator juga dapat mengelola jadwal mata pelajaran dan jadwal mengajar. Administrator dapat mengganti modul dengan meng-upload modul baru pada halaman Tambah Data Mata Pelajaran.

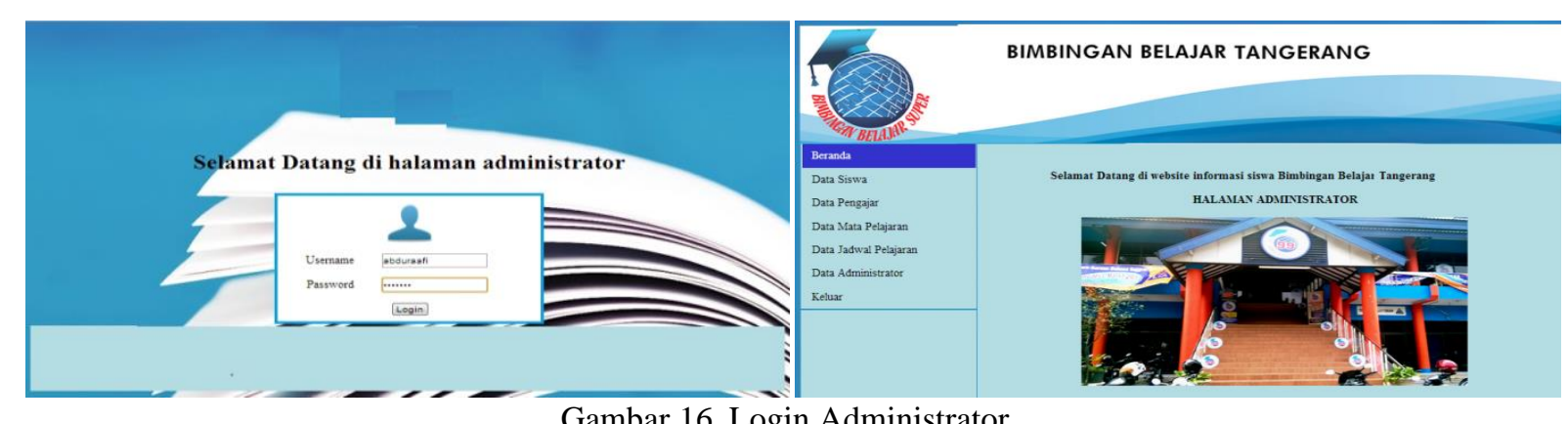

Gambar 16. Login Administrator 


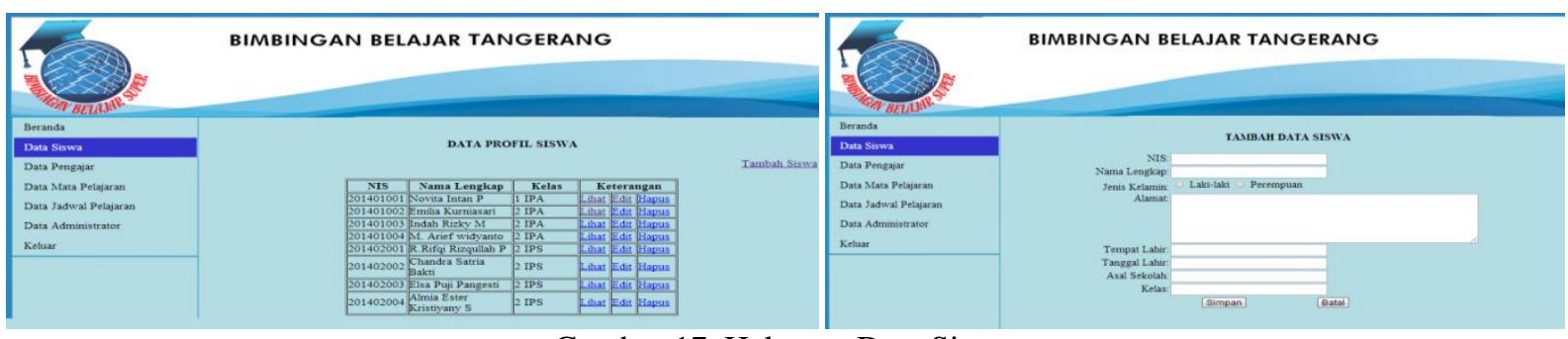

Gambar 17. Halaman Data Siswa

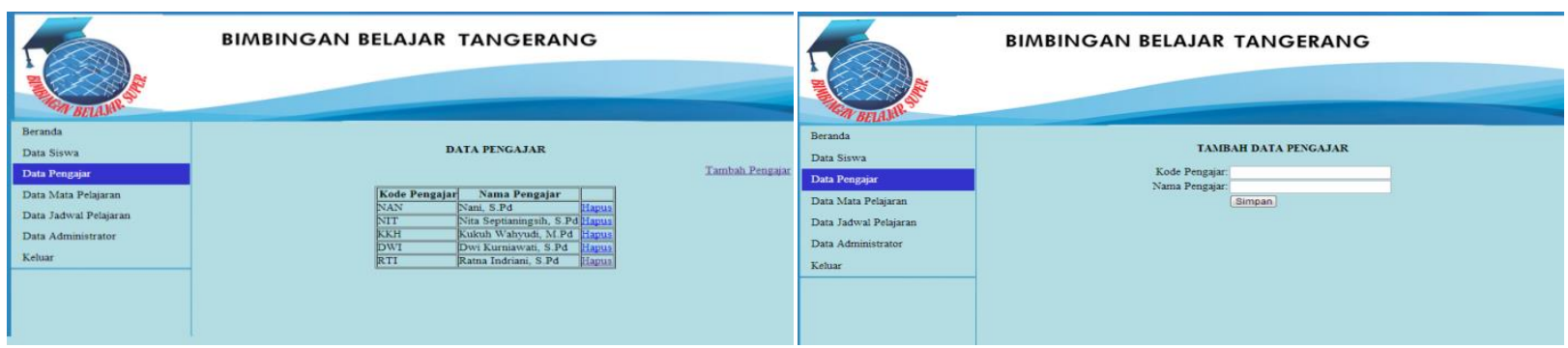

Gambar 18. Halaman Data Pengajar

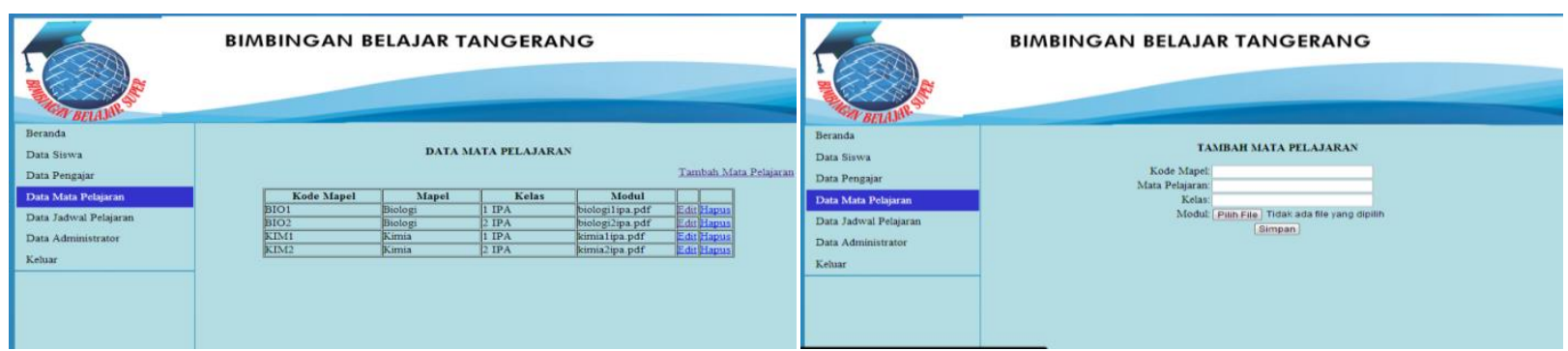

Gambar 19. Halaman Data Mata Pelajaran
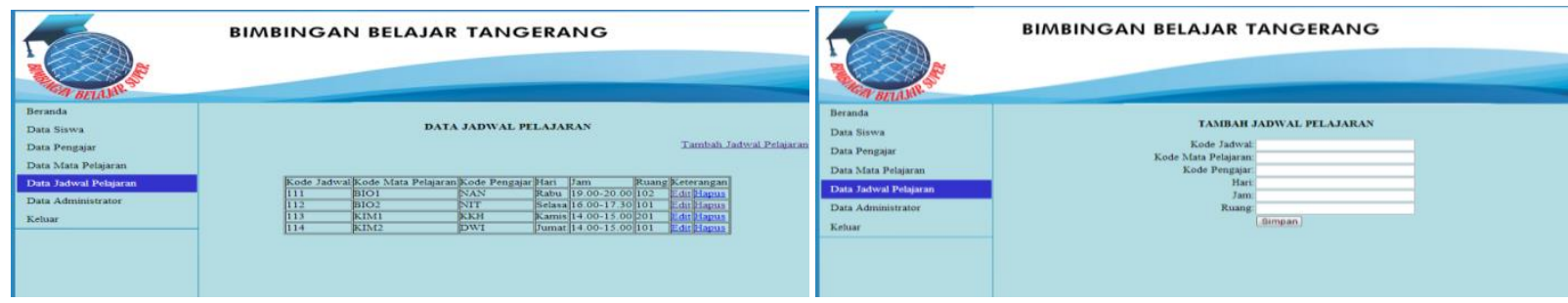

Gambar 20. Halaman Data Jadwal Pelajaran

2. Pada halaman user (siswa), siswa dapat login dengan akun pribadi yaitu Nomor Induk dan password yang berupa kombinasi tanggal lahir siswa. Siswa dapat melihat data pribadi dan mengubahnya bila data yang tertera belum benar. Setelah itu, siswa dapat melihat informasi jadwal mata pelajaran bimbingan. Siswa dapat melihat dan mengunduh materi dan soal berformat softcopy(.pdf).
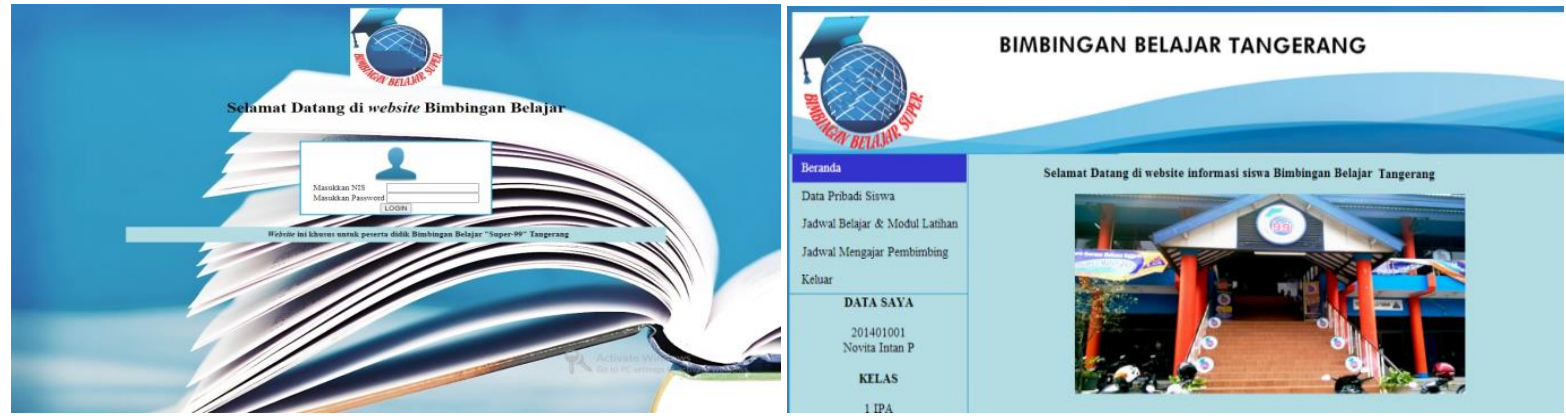

Gambar 21. Halaman Index (Beranda) User 

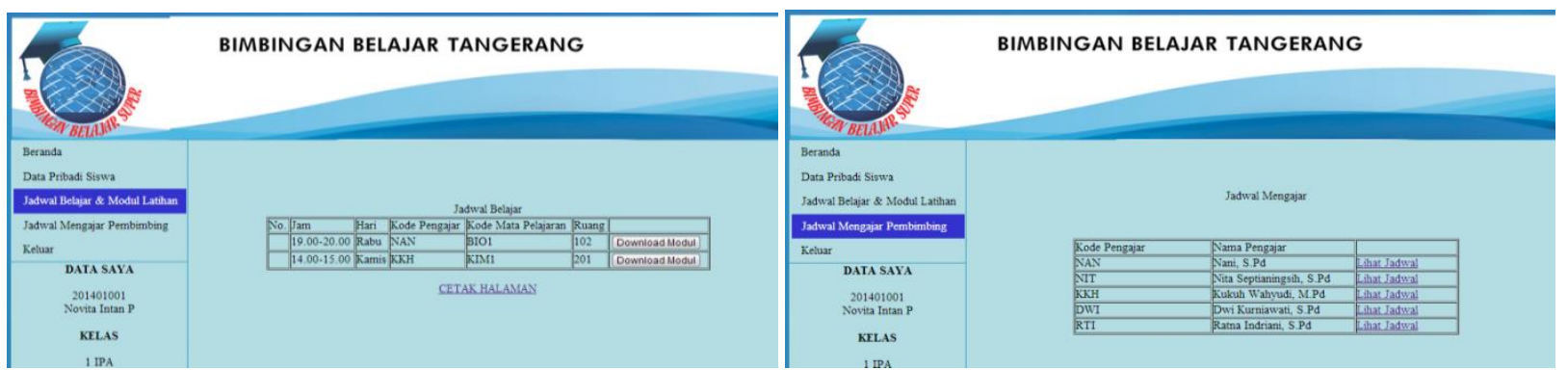

Gambar 22. Halaman Jadwal Belajar Mengajar

\subsection{Tahap Pengembangan Program (Development)}

Tabel 5. Tabel Pengembangan Program

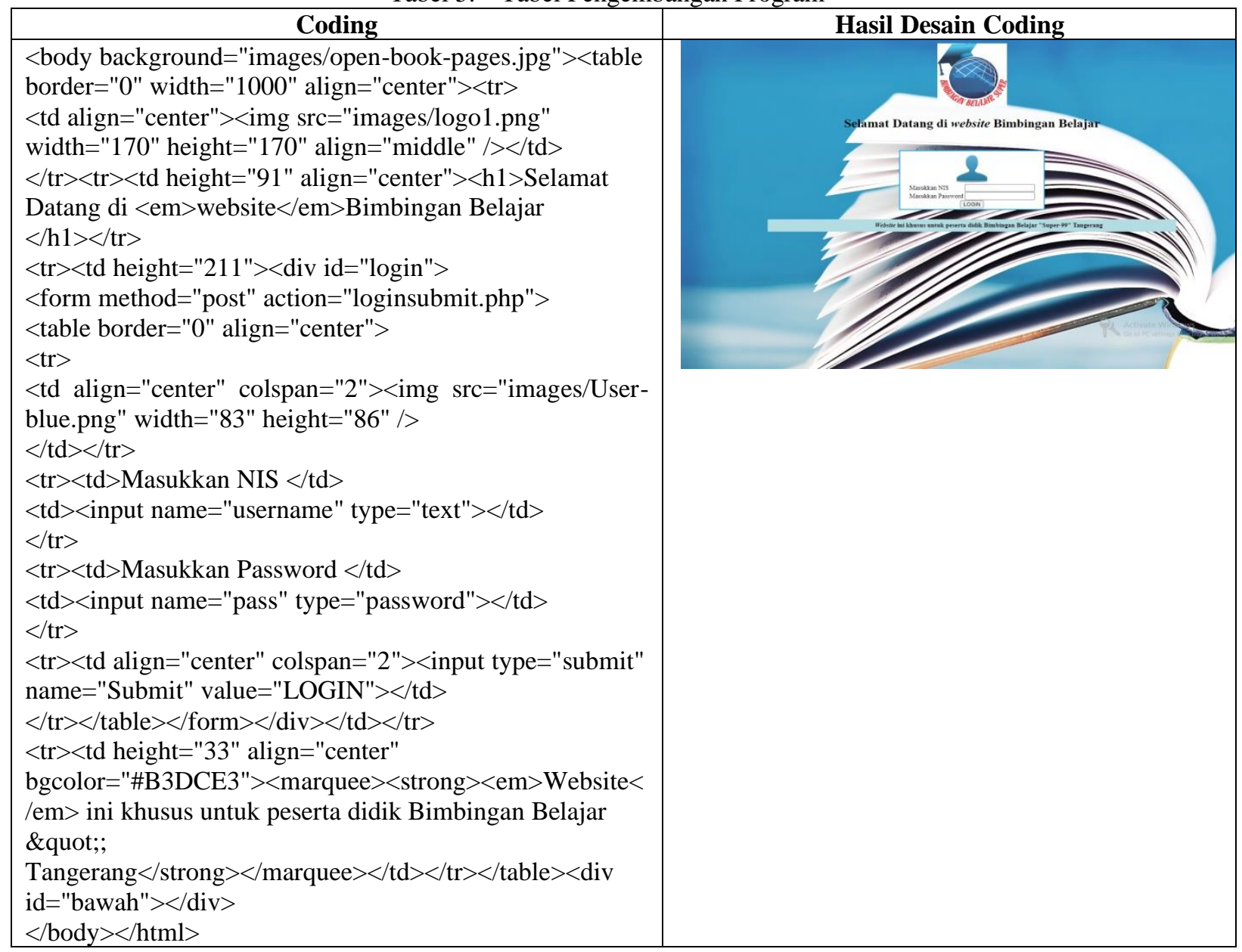

\subsection{Tahap pengujian (testing)}

1. Pengujian terhadap HalamanLogin

\begin{tabular}{|c|c|c|c|c|}
\hline No & $\begin{array}{l}\text { Skenario } \\
\text { Pengujian }\end{array}$ & $\begin{array}{l}\text { Hasil yang } \\
\text { Diharapkan }\end{array}$ & Pengujian & Hasil Pengujian \\
\hline 1 & $\begin{array}{l}\text { Mengisi Username: } \\
\text { kosongPassword: } \\
\text { andrian }\end{array}$ & $\begin{array}{l}\text { Sistem Error, } \\
\text { dikarenakan } \\
\text { ada BUG }\end{array}$ & Error & \\
\hline
\end{tabular}




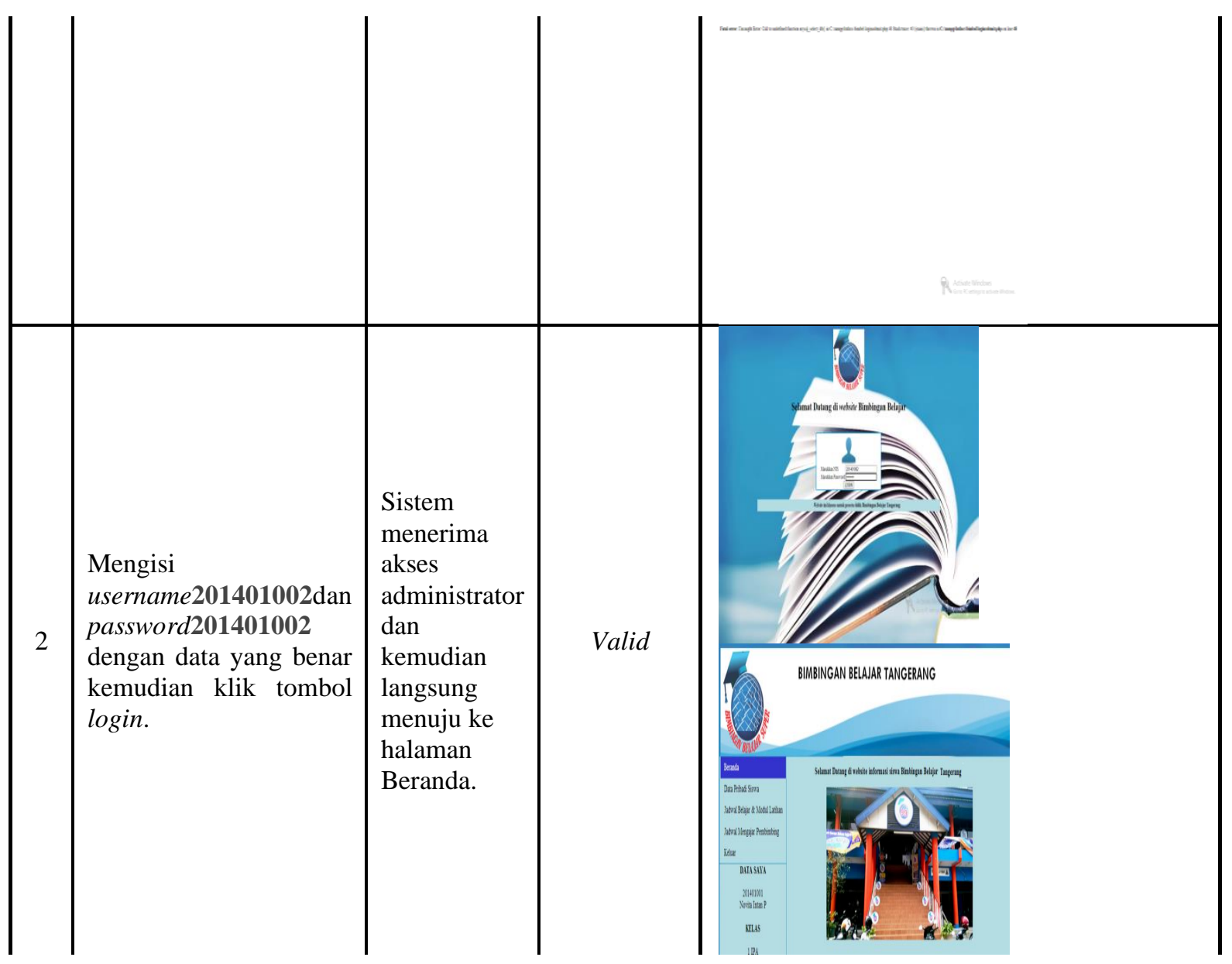

2. Pengujian terhadap Halaman Siswa

Tabel 7. Pengujian terhadap Halaman Siswa

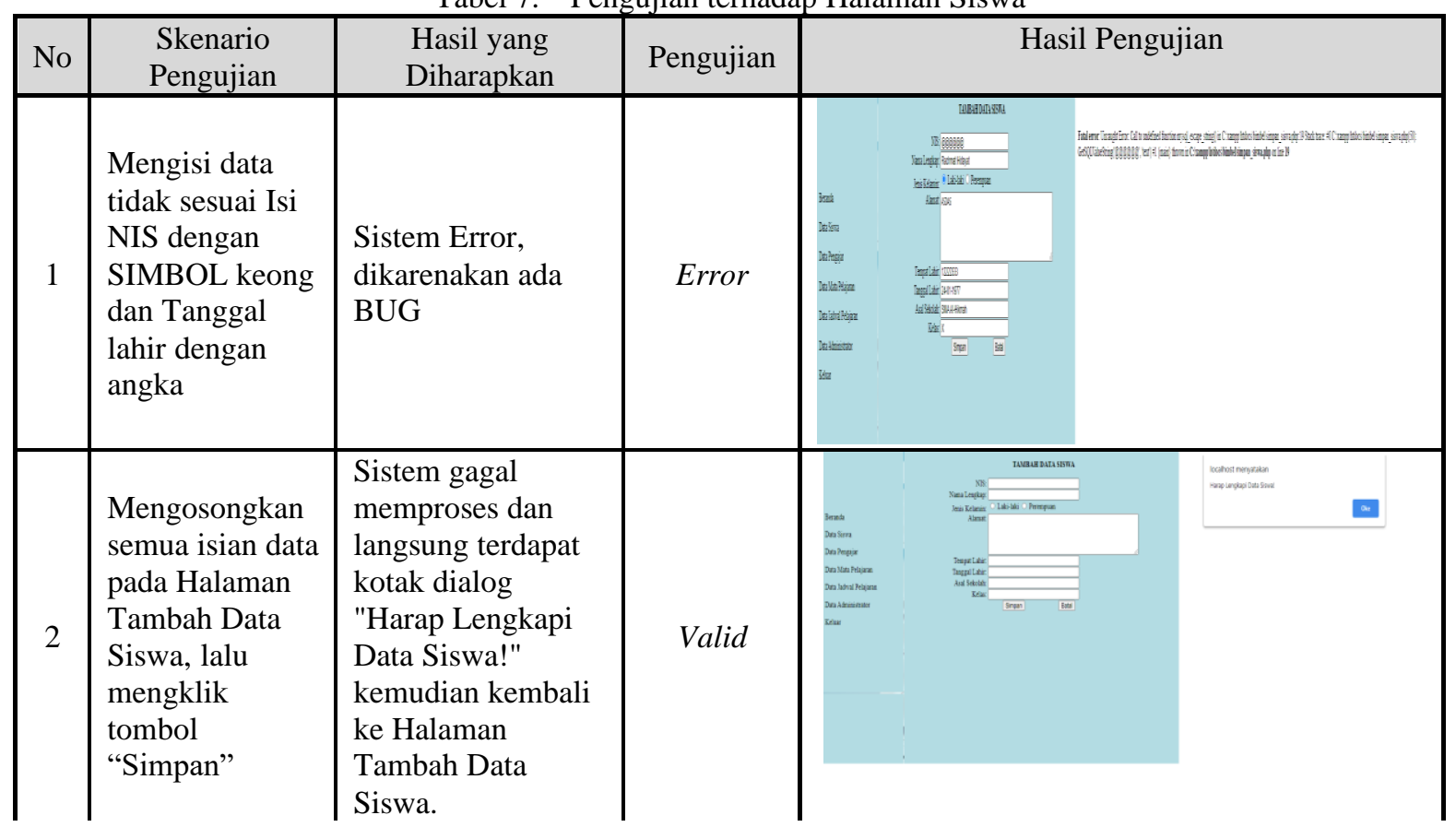

\subsection{Tahap perawatan (maintenance)}

Tahapan terakhir dari metode pengembangan waterfall. Saat ini aplikasi sudah siap di implementasikan dan dijalankan, dikarenakan masih terkendala kebijakan bimbing belajar Bahasa Inggris ELC, Bimbel Umum Rizki, lembaga bimbingan belajar Al-Hikmah belum sama dalam hal sistem penjadwalan, sehingga sulit untuk bisa menerima kebutuhan aplikasi tersebut untuk bisa diterapkan pada masing-masing lembaga. 


\section{KESIMPULAN}

\subsection{Kesimpulan}

Berdasarkan uraian-uraian yang telah penelit sampaikan, maka penulis dapat disimpulkan bahwa:

Aplikasi ini memuat basis data pengolahan penjadwalanbelajar mengajar secara online, sehingga dapat digunakan menjadi informasi yang dibutuhkan oleh Pengajar, Siswa dan administrator, memiliki keuntungan sebagai berikut:

a. Dapat diakses dari mana saja dan kapan saja melalui jaringan internet.

b. Peningkatan efisiensi dan efektivitas dalam proses penerimaan informasi yaitu jadwal belajar mengajaruntuk Pengajar dan siswa.

\subsection{Saran}

Berdasarkan kesimpulan di atas, maka peneliti memberikan saran sebagai alternatif pemikiran dengan harapan agar aspek ilmu pengetahuan tidak bersifat monoton dan terpaku pada disiplin dari ilmu pengetahuan itu sendiri, Adapun saran-saran yang dapat peneliti sampaikan adalah sebagai berikut:

a. Aplikasi website yang telah dibuat hendaknya dioperasikan secara baik dan benar untuk mencapai tujuan yang diharapkan.

b. Selalu mengolah jadwal belajar mengajar sesuai data yang sebenarnya dan menghindari kesalahan yang terdapat di website dengan yang tertera.

c. Untuk meningkatkan kinerja dalam pengaplikasian website ini maka sebaiknya diadakan pengembangan aplikasi mulai dari tampilan halaman website hingga pemeliharaannya sampai membuat backup database.

\section{UCAPAN TERIMA KASIH}

Ucapan terima kasih dapat diperuntukkan kepada pihak-pihak yang telah membantu dalam penulisan, instansi yang menjadi objek penulisanBimbel Bahasa Inggris ELC, Bimbel Umum Rizki, Lembaga Bimbingan Belajar Al-Hikmah, bisa juga kepada pihak yang membantu dalam publikasi artikel.

\section{REFERENSI}

[1] E. Indrayani, "Pengelolaan Sistem Informasi Akademik Perguruan Tinggi Berbasis Teknologi Informasi dan Komunikasi (TIK)," J. TIK Univ. Pendidik. Indones., vol. 12, 2011.

[2] I. Sommerville, Software Engineering, Eight. 2007.

[3] A. Kadir, Pengenalan Sistem Informasi. CV Andi Offset, 2003.

[4] Fathansya, Basis Data. Bandung: Informatika, 2012.

[5] R. . Pressman, Rekayasa Perangkat Lunak, Pendekatan. Yogyakarta: Andi Offset, 2015.

[6] A. Saputra, SistemInformasiNilaiAkademikuntukPanduanSkripsi. Jakarta: PT Elex Media Komputindo, 2012.

[7] H. Al Fatta, Rekayasa Sistem Pengenalan Wajah. Membangun sistem Presensi Karyawan Menggunakan Microsoft Visual Basic 6.0 dan Microsoft Acces. Yogyakarta: C.V.Andi Offset, 2009.

[8] H. Prihatna, Petunjuk Struktur Navigasi. Jakarta: CV. Andi Offset, 2008. 